\title{
Effect of Feeding Frozen Silage on the Milk Production of Dairy Cattle
}

\author{
Masahiro OKaмoTo \\ Shintoku Animal Husbandry Experiment Station, \\ Shintoku-machi, Hokkaido 081
}

(Received October 1, 1979)

\begin{abstract}
The effect of feeding frozen high moisture timothy silage on the milk production of dairy cattle was investigated with six lactating Holstein-Friesian cows in a double reversal design. Moisture content and digestible energy content of the silage were $78 \%$ and $2.96 \mathrm{Mcal} / \mathrm{kg} \mathrm{DM}$, respectively. The silage unloaded from a silo was devided into two portions. Then, a portion was left in the open air overnight for preparing the frozen silage and the other was kept in the barn (control). Average temperature of the frozen silage and the control silage were $-10^{\circ} \mathrm{C}$ and $2^{\circ} \mathrm{C}$, respectively. There were no significant differences between the treatments in the feeds and nutrient intakes. Actual milk yield, fat corrected milk yield, milk protein production and milk fat production of cows fed the frozen silage were significantly lower than those of cows fed the control silage. The difference in 'heat of warming' between the treatments calculated to be over 3 Mcal per head per day. These results suggest that 'heat of warming' could reach the values which affect the milk production when dairy cows are given large amount of frozen high moisture silage.
\end{abstract}

Jpn. J. Zootech. Sci., $51(6): 417-421,1980$

In Hokkaido, the northernmost of the four main islands of Japan, silage is often frozen up during the winter season, and hence the dairy cows in Hokkaido apt to eat frozen silage frequently in the season ${ }^{1,2}$.

The changes in chemical composition ${ }^{3,4)}$ and digestibility ${ }^{5)}$ of freeze-stored experimental herbage have been studied, however, we have scanty informations about the effect of feeding frozen silage on the physiology of ruminants. Oкамото ${ }^{6}$ showed that the feeding frozen high moisture grass silage to sheep resulted in a considerable decrease in the eating rate, some depression of ruminal and rectal temperature and higher heart rate than that of the sheep fed unfrozen silage during and some time after feeding. However, no significant effect on rumen fermentation was observed.

Little information is available about the effect of feeding frozen silage on the productivity. The purpose of the present study was to determine the effect of frozen silage feeding on the milk productivity of dairy cattle.

\section{Materials and Methods}

Six second- to fifth-lactation Holstein-Friesian cows weighing 590 to $660 \mathrm{~kg}$, at 9 to 17 weeks postpartum, were assigned in a double reversal design. Each experimental period was 18 days comprised of a 10-day standardization period and an 8-day data collecting period. Every day, the timothy silage unloaded from a silo was devided 


\section{OKAMOTO}

Table 1. Average outdoor and barn temperature (Mean $\pm \mathrm{SD}$ ) in the each experimental period.

\begin{tabular}{lrrr}
\hline & \multicolumn{3}{c}{ Experimental period } \\
\cline { 2 - 4 } & \multicolumn{1}{c}{ I } & II & \multicolumn{1}{c}{ III } \\
Out door temperature $\left({ }^{\circ} \mathrm{C}\right)$ & & \\
Mean & $-9.0 \pm 2.4$ & $-10.6 \pm 3.9$ & $-9.7 \pm 5.2$ \\
Mean max. & $-3.9 \pm 1.7$ & $-5.9 \pm 2.2$ & $-3.1 \pm 4.4$ \\
Mean min. & $-13.9 \pm 3.8$ & $-15.3 \pm 6.2$ & $-16.2 \pm 7.3$ \\
Barn temperature $\left({ }^{\circ} \mathrm{C}\right)$ & & \\
Mean & $3.2 \pm 2.2$ & $1.9 \pm 1.9$ & $1.5 \pm 2.4$ \\
Mean max. & $4.8 \pm 1.6$ & $3.1 \pm 1.5$ & $4.0 \pm 1.9$ \\
Mean min. & $0.1 \pm 2.0$ & $-1.0 \pm 1.2$ & $-1.8 \pm 2.3$ \\
\hline
\end{tabular}

into two portions and packed in cloth bags coated with rubber. Then, the one was left in the open air overnight for preparing the frozen silage and the other was kept in the barn (control). Average outdoor and barn temperatures in each experimental period were shown in Table 1.

The cows were fed twice daily $25 \mathrm{~kg}$ of timothy silage frozen or unfrozen (control), $0.75 \mathrm{~kg}$ of timothy hay and one-half the weights of concentrate mixture at $1 \mathrm{~kg}$ per $4 \mathrm{~kg}$ of daily milk production. It was observed that cows spent more time in eating the frozen silage than the control silage. Most of the frozen silage offered was eaten within 150 minutes, except in case the silage was frozen too hard to eat readily. Even five to ten hours after feeding, the leftover silage was often still frozen.

Chemical and digestible nutrient compositions of these feeds were shown in Table 2. The digestible nutrient compositions of these feeds were determined at the maintenance intake in a 12-day digestibility trial using four sheep per feeds. The cows were in standings which prevented feeds being stolen by neighbours. Salt licks, containing trace minerals, and water were always accessible.

Milk production and feed intake during the final 8 days of each 18 -day period were used to assess lactation. Milk samples taken from two morning and two evening milkings were analyzed for milk fat, protein and total solids by milko-tester ${ }^{\text {?), pro- }}$ milk ${ }^{8)}$ and TMS equipment (Nihon Yakin Kogaku Kogyo Co., Ltd.), respectively.

Table 2. Chemical and digestible nutrient composition of the feeds.

\begin{tabular}{cccccccc}
\hline Feeds & $\begin{array}{l}\text { Dry } \\
\text { matter }\end{array}$ & $\begin{array}{l}\text { Crude } \\
\text { protein }\end{array}$ & NDF1) & ADF & DCP8) & TDN4) & $\begin{array}{c}\text { Digestible } \\
\text { energy }\end{array}$ \\
\hline & $(\%)$ & - & & (as $\%$ of DM) & & (Mcal/kgDM) \\
Silage & 21.9 & 11.8 & 61.1 & 38.9 & 7.1 & 67.1 & 2.96 \\
$\begin{array}{c}\text { Concentrate } \\
\text { mixture }\end{array}$ & 88.0 & 19.3 & - & - & 15.0 & 80.1 & 3.43 \\
Hay & 83.9 & 8.7 & 70.9 & 42.1 & 4.9 & 52.6 & 2.34 \\
\hline
\end{tabular}

1) Neutral-detergent fiber. 2) Acid-detergent fiber. 3) Digestible crude protein.

4) Total digestible nutrients. 
Feeds and fecal samples were analyzed for proximate constituents according to A. $O$. A.C. procedures ${ }^{9)}$, for neutral detergent fiber $^{10)}$ and for acid detergent fiber ${ }^{11}$. Gross energy was determined by automatic bomb calorimeter (Shimadzu Seisakusho Ltd. CA-3).

\section{Results and Discussion}

Feed intake and digestible nutrient intake were shown in Table 3. Grass silage intakes were similar for the cows fed the frozen silage and the cows fed the control silage. There were no significant differences between the treatments in the feeds and digestible nutrients intakes. Based on Japanese feeding standard estimated requirements, both ration fed to cows in these treatments were consumed in the amounts adequate to meet the digestible crude protein (DCP), total digestible nutrients (TDN) and digestible energy (DE) requirements for maintenance and production.

The differences in milk yield as well as fat corrected milk (FCM) yield between the treatments were small but statistically significant. Solid corrected milk (SCM) yields of cows receiving the frozen silage tended to be lower $(\mathrm{P}<.10)$ compared to the control silage. The milk protein and milk fat production were significantly lower ( $\mathrm{P}<$ $.05)$ and the milk solids-not-fat (SNF) production tended to be lower $(P<.10)$ for the frozen silage treatment. However, the milk composition was little affected by feeding the frozen silage. Differences in body-weight change between the treatments were not significant.

One of the cows fed control silage at period III distorted the hock joint and milk production of the cow depressed considerably in several days of standardization period. This effect was not eliminated completely even in the collecting period. Consequently, the difference of milk production between the treatments might be slightly underestimated.

Despite the little differences in DCP, TDN and DE intakes between the treatments, the production of actual milk, FCM, milk fat and milk protein were slightly

Table 3. Daily intake of feeds and digestible nutrients.

\begin{tabular}{|c|c|c|c|c|c|}
\hline & \multicolumn{2}{|c|}{ Treatment } & \multirow{2}{*}{$\bar{d}_{1}$} & \multirow{2}{*}{$\bar{d}_{2}$} & \multirow{2}{*}{ SD } \\
\hline & Frozen & Control & & & \\
\hline Silage (kg) & 47.2 & 48.0 & 0.02 & -3.03 & 1.46 \\
\hline $\begin{array}{l}\text { Concentrate } \\
\text { mixture }(\mathrm{kg})\end{array}$ & 4.3 & 4.3 & 0.13 & 0.13 & 0.17 \\
\hline Hay $(\mathrm{kg})$ & 1.5 & 1.5 & -0.1 & 0.0 & 0.10 \\
\hline $\begin{array}{l}\text { Digestible } \\
\text { energy (Mcal) }\end{array}$ & $\begin{array}{l}46.5 \\
(105 \%)\end{array}$ & $\begin{array}{l}47.1 \\
(106 \%)\end{array}$ & 0.28 & -1.23 & 0.77 \\
\hline $\begin{array}{l}\text { Total digestible } \\
\text { nutrients }(\mathrm{kg})\end{array}$ & $\begin{array}{l}10.6 \\
(105 \%)\end{array}$ & $\begin{array}{l}10.7 \\
(106 \%)\end{array}$ & 0.12 & -0.17 & 0.22 \\
\hline $\begin{array}{l}\text { Digestible crude } \\
\text { protein (kg) }\end{array}$ & $\begin{array}{l}1.36 \\
(120 \%)\end{array}$ & $\begin{array}{c}1.38 \\
(122 \%)\end{array}$ & 0.02 & -0.04 & 0.05 \\
\hline
\end{tabular}

$\bar{d}_{1}:$ (Control-2Frozen + Control) $/ 3 . \quad \vec{d}_{2}$ : (Frozen -2 Control + Frozen) $/ 3$.

( ): Percentage of requirements for maintenance and production. 
OKaMoTo

Table 4. Lactation performance.

\begin{tabular}{|c|c|c|c|c|c|}
\hline & \multicolumn{2}{|c|}{ Treatment } & \multirow{2}{*}{$\bar{d}_{1}$} & \multirow{2}{*}{$\bar{d}_{2}$} & \multirow{2}{*}{$\mathrm{SD}$} \\
\hline & Frozen & Control & & & \\
\hline \multicolumn{6}{|c|}{ Production (daily means) } \\
\hline Milk yield (kg) & $17.2 *$ & 17.4 & 0.43 & -0.61 & 0.45 \\
\hline $\begin{array}{l}\text { Fat corrected } \\
\text { milk yield }(\mathrm{kg})\end{array}$ & $15.5^{*}$ & 15.9 & 1.26 & -0.12 & 0.44 \\
\hline $\begin{array}{l}\text { Solids corrected } \\
\text { milk yield }(\mathrm{kg})\end{array}$ & 15.1 & 15.5 & 0.91 & -0.75 & 0.74 \\
\hline Milk fat (g) & $578^{*}$ & 594 & 72.5 & 8.3 & 18.7 \\
\hline Milk protein (g) & $519^{*}$ & 555 & 43.6 & -103.8 & 58.2 \\
\hline Solids-not-fat (g) & 1410 & 1450 & 10.0 & -138.5 & 90.0 \\
\hline \multicolumn{6}{|l|}{ Milk composition } \\
\hline Milk fat $(\%)$ & 3.44 & 3.36 & 0.32 & 0.18 & 0.10 \\
\hline Milk protein (\%) & 3.04 & 3.22 & 0.11 & -0.59 & 0.42 \\
\hline Solids-not-fat (\%) & 8.23 & 8.31 & -0.11 & -0.45 & 0.33 \\
\hline $\begin{array}{l}\text { Body weight change } \\
\text { (kg/18 days) }\end{array}$ & -6.8 & 1.2 & -3.7 & -36.0 & 29.4 \\
\hline
\end{tabular}

but significantly lower for the frozen silage treatment. The only noteworthy difference between the treatments was the temperature of the silage. Average temperatures of the frozen silage and the control silage were about $-10^{\circ} \mathrm{C}$ and $2^{\circ} \mathrm{C}$, respectively. Heat of warming $(\mathrm{Hw})^{12)}$ was calculated for the frozen silage and the control silage to be around $100 \mathrm{kcal} / \mathrm{kg}$ silage and $30 \mathrm{kcal} / \mathrm{kg}$ silage, respectively. Most of the difference of $\mathrm{Hw}$ was attributable to the heat of fusion. The difference in $\mathrm{Hw}$ between the silage amounted to as much as over $3 \mathrm{Mcal}$ per day per head. This indicated that the cow fed frozen silage had to spend over $3 \mathrm{Mcal}$ more to warm the feed than the cows fed control silage. It could be considered that the main reason for the observed discrepancies in milk production were the difference of $\mathrm{Hw}$ between the treatments. BLAXTER $^{12)}$ said that $\mathrm{Hw}$ is usually a minor component of the overall heat loss, but one not to be neglected. Окамото ${ }^{6)}$ pointed out that $\mathrm{Hw}$ became considerable when frozen high moisture silage was fed. The results of the present study indicated that Hw could reach the values which affect the milk production when dairy cows were given large amount of frozen succulent feed.

\section{References}

1) Tsubomatsu, K. and H. Saito, Bull. Hokkaido Prefect. Agric. Exp. Stn., 10: 15-30. 1963.

2) Doнкоsнi, J., J. Soc. Agric. Structures Jpn., 3: 20-28. 1972.

3) MacRae, J.C., N. Z. J. Agric. Res., 13: 45-50, 1970.

4) Bryant, A. M. and R.P. Newth, N. Z. J. Agric. Res., 18: 375-378. 1975.

5) Mrnson, D. J., J. Brit. Grassld. Soc., 21: 123-126. 1966.

6) Окамото, M., Jpn. J. Zootech. Sci, 44: 440-446. 1973.

7) Mc Dowell, A. K. R., J. Dairy Res,, 35: 181-189. 1968.

8) Kuwabara, H., T. Watanabe, T. Ryoki and T. Nagasawa, Nippon Nogeikagaku Kaishi 39: 239-241. 1965. 
9) Association of Official Analytical Chemists, Official methods of analysis. 11th ed. Wash. ington, DC. 1970.

10) Van Soest, P. J. and R. H. Wine, J. Ass. Offic. Agr. Chem., 50: 50-55. 1967.

11) Van Soest, P. J., J. Ass. Offic. Agr. Chem., 46: 829-835. 1963.

12) Blaxter, K. L., The Energy Metabolism of Ruminants. 1st ed. 116-148. Hutchinson Sci. and Tech., London. 1962.

\section{凍結サイレージの給与が乳生産に及ぼす影響 \\ 岡本全弘 \\ 新得畜産試験場, 北海道新得町 081}

\begin{abstract}
凍結したサイレージの給与が乳生産に及活す影響を知 るため，ホルスタイン種の泌乳牛6碩を供試し，反転飼 養試験法にて泌乳試験定実施した。供試したサイレージ 以水分含有率 $78 \%$ ，乾物中の可消化エネルギー含量 2.96 $\mathrm{Mcal} / \mathrm{kg}$ のチモシーサイレージである: サイ り出したサイレージは二分し，片方を屋外に放置するこ とにより凍結させた。凍結サイレージの平均温度は約

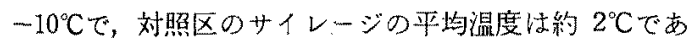
った．铝料や可消化栄養素の摄取量は処理間に差はな
く，飼養標準の要求量を满たしていた，凍結サイレージ を給与した試験区の牛は対照区の牛に比べて，実乳量， $\mathrm{FCM}$ 量, 乳蛋白質量および拜脂肪量が有意に低か。 た. 処理間の Heat of warming の差は1日1頭当り 3 Mcal 以上に達したものと計算された。乳牛に凍絬状態 にある高水分サイレージを多量に給与する際の Heat of warming は，乳量を低下させる程度に大きなものと考 察した.

日畜会報，51(6)：417-421，1980 